\title{
209. Fehler und Gefahren bei der chirurgischen Therapie des Morbus Crohn
}

\author{
W. Fasching, H. Lochs, A. Staffen und E. Wolner \\ II. Chirurgische Universitätsklinik und I. Universitätsklinik für Gastroenterologie und Hepatologie Wien, \\ Spitalgasse 23, A-1030 Wien
}

\section{Pitfalls and Risks in the Surgical Therapy in Crohn's Disease}

Summary. Experience in the multidisciplinary care of patients with Crohn's disease is described from the results of 123 operations with mortality of $3.78 \%$. In special patients, who need a respite, an earlier operation should be considered even when indications are relative. Because of a high incidence of complications such as enterocutaneous fistulas, prophylactic appendectomy in cases of ileocolitis and tube drainage of the abdomen should be avoided. Semiconservative therapy in anal lesions is also mandatory.

Key words: Crohn's disease - Surgery - Results - Complications.

Zusammenfassumg. Die Erfahrungen, die bei der multidisziplinären Betreuung von Patienten mit M. Crohn und bei 123 Operationen mit einer Letalität von 3,78\% gewonnen wurden, werden dargestellt: Bei bestimmten Patienten, die eine ,,medizinische Atempause" brauchen, sollte man auch bei relativer Indikation an eine frühere Operation denken. Vermeidung der prophylaktischen Appendektomie bei Ileocolitis. Vermeidung von intraabdominellen Drainagen. Semikonservative Therapie im Analbereich.

Schliisselwörter: Morbus Crohn - Chirurgie - Ergebnisse - Komplikationen. 